\title{
The Emergence of Common Market in West Africa: An Examination of Cross Culture and Ethnographic Marketing System of Alaba International Market, Lagos-Nigeria
}

\author{
Mufutau Akanbi Awoniyi \\ Department of Marketing, Faculty of Management Sciences, Lagos State University, Ojo, Lagos, Nigeria \\ Email: mugafric2001@yahoo.com
}

Received 1 August 2015; accepted 23 February 2016; published 26 February 2016

Copyright (C) 2016 by author and Scientific Research Publishing Inc. This work is licensed under the Creative Commons Attribution International License (CC BY). http://creativecommons.org/licenses/by/4.0/ cC) (i) Open Access

\section{Abstract}

Alaba International Market in Lagos, Nigeria for years is noted and opened for many imports of all kinds of products and gains popularity along West Africa Countries for cheap and affordable products. The market particularly serves other neighboring countries such as Togo, Benin, Ghana, and even beyond. Some groups of traders especially the Ibo tribes of Nigeria are known to specialize in assembling, fabricating and importing cheap and locally made components and parts of all kinds of products-electronics and households to suit all types of categories of consumers. Alaba International Market has also gained popularity in Nigeria and across West Africa countries as an accessible market for all kinds of imports particularly electronics and household items from China, Japan, India and other far East. The popularity of the market is made possibly because of the fact that Nigerians and others West Africans are quite receptive to foreign goods, products and services. The research work examines the structure, system, marketing practices, consumer behaviors, and the marketing patterns of the various ethnic groups operating at the Alaba International Market as well as performance of Business Enterprises in Alaba International Market, Lagos State. The acceptance and recognition of Alaba International Market in 0jo, Lagos, Nigeria are the major element and development in cross cultural and ethnographic marketing system (EMS) in Nigeria and the world. The study also examines the effects of Alaba International Market in the economic development of small scale enterprises in Lagos State. Using and applying the Modified Purchase Decision Making Process (PDMP), a number of shoppers, buyers and consumers patronizing Alaba International Market and their behavior were examined to determine factors that influence the patronage and acceptance of the market among consumers, buyers and shoppers across West Africa countries. The study shows that $82 \%$ of the entrepreneurs made up of small and medium enterprises of the market are from the Ibo ethnic group of Nigeria. Consumers' preference to imported goods has contributed to the booming of the market all the year round which also contri- 
butes to the development, expansion, success and growth of small and medium scale enterprises in Lagos State.

\title{
Keywords
}

\author{
Alaba International Market, Ethnographic Marketing, Ethnic Marketing, Purchase Decision Making \\ Process, Small and Medium Scale Enterprises
}

\section{Introduction}

Alaba International Market in Ojo area of Lagos State, Nigeria facilitates the emergence of the biggest and largest market in West Africa. The market serves other neighboring countries such as Togo, Benin and Ghana, among others. Some groups of traders especially the Ibo tribes of Eastern part of Nigeria are known to have specialized in assembling, fabricating and importing cheap and locally made components and parts of all kinds of products-electronics and households to suit all types of categories of consumers. This ethnic group constitutes the major players of the market. Alaba International Market was able to gain popularity in Nigeria and among West Africa countries as it remains as an easy, accessible and open market for all kinds of imports especially electronics, households' items from China, Japan, India and other Far East countries. The popularity of the market was made possibly because of the fact that Nigerians and other West Africa nations are quite receptive to foreign goods and products, regardless of quality, durability and product life. The habit, belief and notion of using imported items are a sort of satisfaction that the people of Nigeria cherish much.

The study investigates Ethnographic Marketing System, patterns, structure among business enterprises in Alaba International Market and it analyzes the relationship between marketing patterns and practices.

The study carried out here is exploratory in nature aims to answer if Alaba International Market is an ethnic control, and if it serves as dumping ground for substandard products in West Africa and if that has contributed to the growth and development of small scale enterprises in the state. The application of Street Level Marketing (SLM) theory [1] was applied to determine acceptance and popularity of the market. Stephen and Susan Daun [1] define Street Level Marketing as the marketing activities undertaken by a member of a psychological niche to further the adoption of an idea, good or service developed within the niche, to meet the specific needs or wants of the niche. The prices you pay for Alaba product sometimes depend on your bargaining power and negotiation strategy (Figure 1). Some of the products and services of Alaba Market are of road side operation and negotiation. There are always touts or agents that move around the market or operate on every street and every line of shops to pursue and persuade potential customers to buy from a particular store (Figure 1). And most of the touts or agents are fake sellers or selling substandard products. The pricing system of entrepreneurs of Alaba market depends on how you are being assessed by the seller, i.e. using personality pricing system (Figure 1). Also, the application of the Modified Purchase Decision Making Process (PDMP) (Figure 2), a number of shoppers, buyers and consumers patronizing Alaba International Market and their behaviors were examined to determine factors that influence the patronage and acceptance of the market among consumers and shoppers across West Africa countries. Products' market segmentations, discrimination of products prices and personality selling are believed to be some of the major factors influencing the high patronage of the market by all and sundry. Many people believe that Alaba International Market serves all the categories of buyers, consumers and any income earners.

\section{Background of the Study}

In order to investigate the various factors that influence the emergence and acceptance of the West Africa common market, this paper relies on primary and conceptual findings as there was no known previous studies carried out and documented by any researcher. It is believed that consumers and shoppers across the West-Africa recognition and acceptance of Alaba International Market was as a result of high tastes of foreign and imported goods and items that the people of Nigeria and neighboring countries share in common which are readily available in the market. 


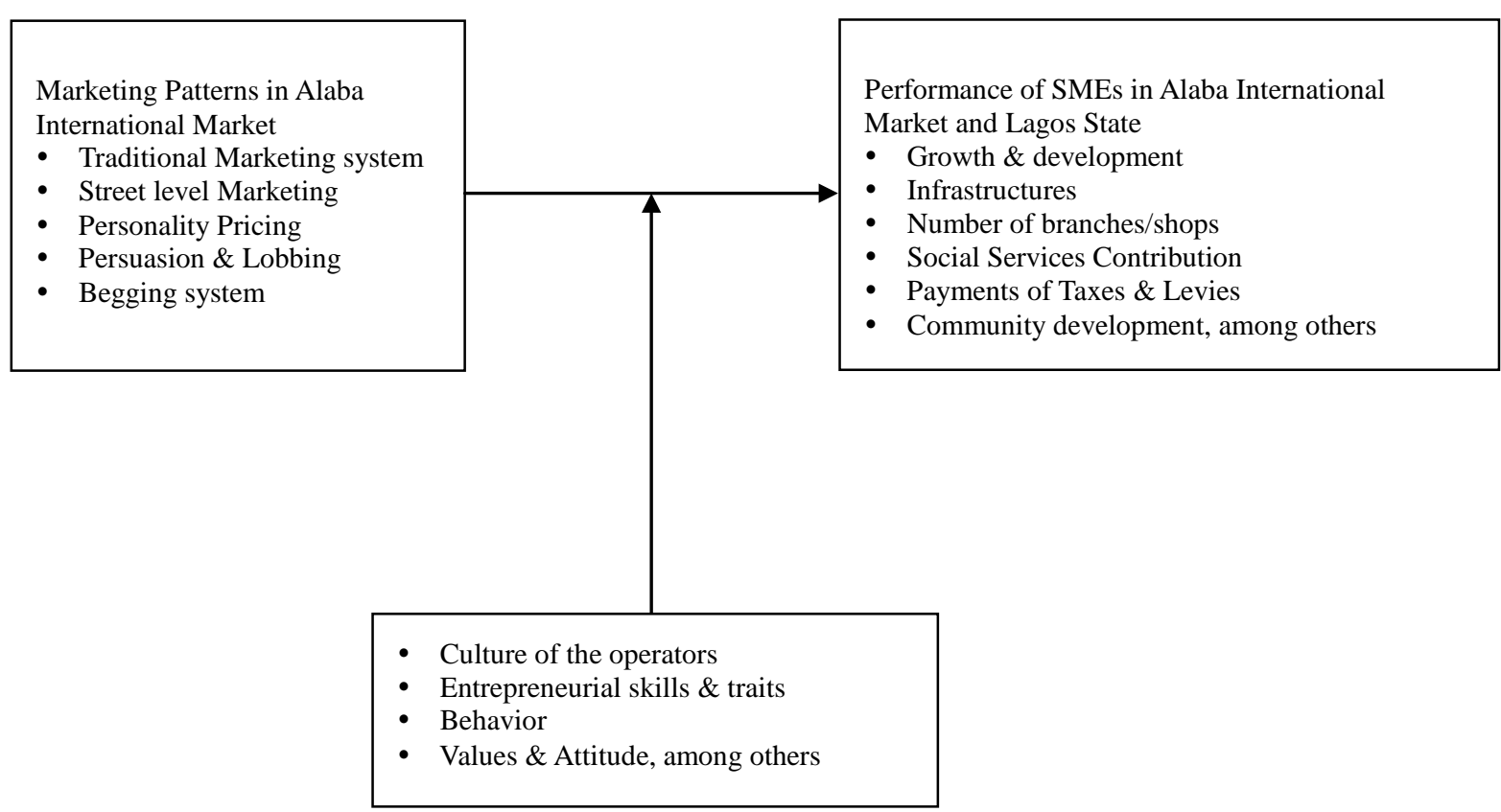

Figure 1. Conceptual framework of Alaba International Market (Source: Research Survey, 2008).

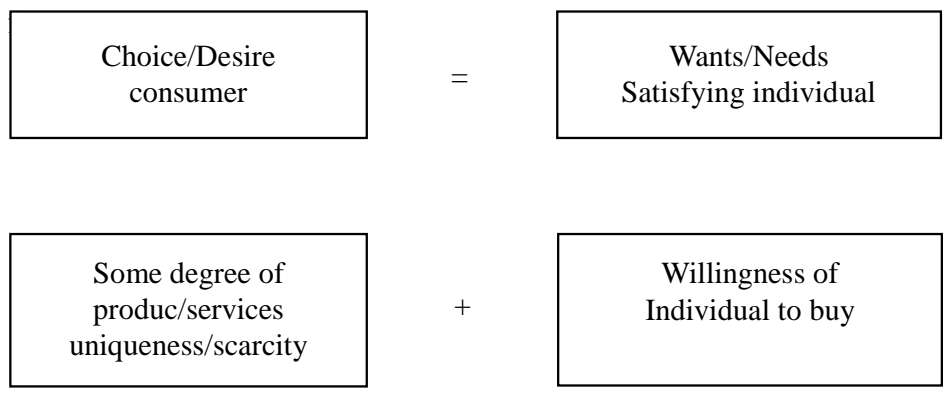

Figure 2. PDMP model.

A number of reasons have been given in the report as useful in explaining the dominance of the market by one ethnic group of Nigeria. The understanding of how culture and environment influences technological innovation and marketing was related to the Ibo's understanding of consumer behavior, and their innovative style of imitation of products and services. In marketing, new products can be described or considered as products with minor or major innovation and the Ibo tribes are fully aware of process innovation.

Innovation is a change in Technology - a departure from previous ways of doing things. Two fundamental types of innovation are the product and the process innovation [2]. Process innovations are changes that affect the methods of producing outputs. Products innovations are changes in the actual output (products and services) of the organization [3].

The Alaba International Market has developed over the years and has attracted many customers along the West African countries. The market has been considered as a bed rock of market and consumers' information on the performance of business enterprises and knowledge to those in academic and professional areas. Yet, research efforts for Small and Medium Scale Enterprises especially from ethnographic approach have not been extended into the operations, functions and marketing patterns of business enterprises in Alaba International Market. Similarly, it has been observed that a certain ethnic group in Nigeria dominates and controls Alaba International Market with peculiar entrepreneurial traits and skills that distinguish them from other ethnic groups in Nigeria which in effect affecting business performance (Figure 1). Most of the previous studies on Nigeria markets focused on trade associations and general market with little attention on ethnographic marketing system and structure. 
The following hypotheses were formulated for this study:

1) there is no significant relationship between the ethnographic marketing patterns (EMPs) and the performance of business enterprises in Alaba International Market (Table 1);

2) Alaba International Market has not been meeting the Industrial Objectives of Lagos State (Table 2);

3) there is no significance relationship between effects of Alaba International Market and economic development of business enterprises in Lagos State (Table 3);

4) there is no significant relationship between ethnic marketing practices and traders of Alaba International Market (Table 4).

Table 1. Relationship between EMPs and performance of SSEs.

\begin{tabular}{|c|c|c|c|c|c|}
\hline \multirow{2}{*}{$\begin{array}{l}\text { Assessment of } \\
\text { ethnographic marketing } \\
\text { patterns of Alaba Market }\end{array}$} & \multicolumn{4}{|c|}{ Performance of small-scale enterprises in Alaba International Market } & \multirow[b]{2}{*}{ Total } \\
\hline & $\begin{array}{l}\text { Provision of } \\
\text { employment } \\
\text { opportunities }\end{array}$ & $\begin{array}{l}\text { Development of } \\
\text { entrepreneurial } \\
\text { skills }\end{array}$ & $\begin{array}{l}\text { The market are } \\
\text { meeting with } \\
\text { standard }\end{array}$ & $\begin{array}{l}\text { The market is in the } \\
\text { direction from wholesalers } \\
\text { to consumers }\end{array}$ & \\
\hline Mostly dominated by Igbo people & $19(52.8 \%)$ & - & - & $17(4.3 \%)$ & $36(9.0 \%)$ \\
\hline It comprises of Ibo, Hausa and Yoruba & - & $36(9.0 \%)$ & $18(4.5 \%)$ & $38(9.5 \%)$ & $92(23.0 \%)$ \\
\hline $\begin{array}{l}\text { Mostly dominated from Eastern part } \\
\text { of the country }\end{array}$ & $83(20.8 \%)$ & $17(4.3 \%)$ & 135(33.8\%) & - & $235(58.8 \%)$ \\
\hline Igbo $80 \%$, Hausa $15 \%$ and Yoruba 5\% & $18(4.5 \%)$ & - & - & $19(4.8 \%)$ & $37(9.3 \%)$ \\
\hline Total & $120(30.0 \%)$ & $53(13.3 \%)$ & 153(38.3\%) & 74(18.5\%) & $400(100.0 \%)$ \\
\hline
\end{tabular}

Field Survey, 2010.

Table 2. Alaba International Market pattern and industrial objectives of Lagos state.

\begin{tabular}{lccccc}
\hline \multicolumn{1}{c}{$\begin{array}{c}\text { Effects of Alaba International } \\
\text { Market on the economic } \\
\text { development of business } \\
\text { enterprises in Lagos }\end{array}$} & $\begin{array}{c}\text { Alaba International Market and Industrial Objectives of Lagos state } \\
\text { Serves as catalyst } \\
\text { for industrial } \\
\text { products }\end{array}$ & $\begin{array}{c}\text { Led to the } \\
\text { improvement of } \\
\text { locally made goods }\end{array}$ & $\begin{array}{c}\text { Acts as raw } \\
\text { materials } \\
\text { for industries }\end{array}$ & $\begin{array}{c}\text { Makes Lagos } \\
\text { state as } \\
\text { industrial state. }\end{array}$ & Total \\
\hline Job opportunities & $5(4.7 \%)$ & - & - & $27(25.2 \%)$ & $32(29.2 \%)$ \\
Provision of credit facilities & $5(4.7 \%)$ & - & - & - & $5(4.7 \%)$ \\
Chance of competition & - & $40(37.4 \%)$ & $10(9.3 \%)$ & - & $50(46.7 \%)$ \\
United against unlawful legislation & - & $5(4.7 \%)$ & $5(4.7 \%)$ & $10(9.3 \%)$ & $20(18.7 \%)$ \\
Total & $10(9.3 \%)$ & $45(42.1 \%)$ & $15(14.0 \%)$ & $37(34.6 \%)$ & $107(100.0 \%)$ \\
\hline
\end{tabular}

Field Survey, 2010.

Table 3. Relationship between effects of Alaba International Market and economic development of business enterprises.

\begin{tabular}{|c|c|c|c|c|c|}
\hline \multirow{2}{*}{$\begin{array}{l}\text { Performance of business enterprises } \\
\text { in Alaba International Market }\end{array}$} & \multicolumn{4}{|c|}{$\begin{array}{l}\text { Effects of Alaba International Market on the economic } \\
\text { development of small-scale enterprises in Lagos }\end{array}$} & \multirow{2}{*}{ Total } \\
\hline & $\begin{array}{c}\text { Job } \\
\text { opportunities }\end{array}$ & $\begin{array}{l}\text { Provision of } \\
\text { credit facilities }\end{array}$ & $\begin{array}{l}\text { Chance of } \\
\text { competition }\end{array}$ & $\begin{array}{c}\text { United against } \\
\text { unlawful legislation }\end{array}$ & \\
\hline Provision of employment opportunities & 101(25.3\%) & - & $19(4.8 \%)$ & - & $120(30.0 \%)$ \\
\hline Development of entrepreneurial skills & - & - & $17(4.3 \%)$ & $36(9.0 \%)$ & $53(13.3 \%)$ \\
\hline The market are meeting with standard & - & - & $153(38.3 \%)$ & - & $153(38.3 \%)$ \\
\hline $\begin{array}{l}\text { The market is in the direction from } \\
\text { wholesalers to consumers }\end{array}$ & $19(4.8 \%)$ & $17(4.3 \%)$ & - & $38(9.5 \%)$ & $74(18.5 \%)$ \\
\hline Total & $120(30.0 \%)$ & $17(4.3 \%)$ & $189(47.3 \%)$ & $74(18.5 \%)$ & $400(100.0 \%)$ \\
\hline
\end{tabular}

Field Survey, 2010. 
Table 4. Relationship between ethnic marketing practices and traders of Alaba market.

\begin{tabular}{|c|c|c|c|c|}
\hline \multirow[b]{2}{*}{ Ethnic Group } & \multicolumn{3}{|c|}{ Ethnic marketing practices among traders in Alaba International Market } & \multirow[b]{2}{*}{ Total } \\
\hline & $\begin{array}{l}\text { They speak Igbo as } \\
\text { the major language }\end{array}$ & $\begin{array}{l}\text { The market consists of } \\
\text { different kinds of tribes }\end{array}$ & $\begin{array}{l}\text { Traders favor fellow customers } \\
\text { from their tribe }\end{array}$ & \\
\hline Yoruba & $14(3.5 \%)$ & $33(8.3 \%)$ & $14(3.5 \%)$ & $61(15.3 \%)$ \\
\hline Igbo & $39(9.8 \%)$ & $254(63.5 \%)$ & $41(10.3 \%)$ & $334(83.5 \%)$ \\
\hline Hausa & - & $4(1.0 \%)$ & - & $4(1.0 \%)$ \\
\hline Others & - & $1(0.3 \%)$ & - & $1(0.3 \%)$ \\
\hline Total & $53(13.3 \%)$ & $292(73.0 \%)$ & $55(13.8 \%)$ & $400(100.0 \%)$ \\
\hline
\end{tabular}

Field Survey, 2010.

\section{An Overview of Marketing}

Marketing has now become the prime focus of any business organization. In the past many business outfits as profit making, nonprofit making and nongovernmental organizations organized and run their business by giving their customers what they thought they wanted. But now any business organizations have to find out what their customers want and then develop the products or services to satisfy their desires and create a repeat purchase [4]. From a macro perspective, marketing can be defined as "bringing about exchanges between individual and/or groups so as to provide satisfaction of a society’s wants and needs. Marketing involves creating products that will satisfy the needs and wants of people. Marketers price those products to give then values and monetary considerations. These products must be put in places where people can buy them. And promotion communicates the marketers' messages to a selected audience. These are the four main activities of marketers. It should be noted that other activities are included in marketing [4].

\section{Market and Function of a Market}

Schewe [4] defines market as a group of people with unsatisfied wants and needs who are willing to exchange and have the ability to buy. Moschandreas [5] also defined a market in his own perspective, as a group of buyers and seller involved in exchanges. Wikipedia [6] stated that in economic, a market is a social structure developed to facilitate the exchange of rights, services or product ownership. Thus, market enables peoples' services, firms and products to be evaluated and priced. A market allows buyers and seller to discover information and carryout a voluntarily exchange of goods and services. This is commonly done through trade.

The function of a market as stated by Wikipedia [6] requires at a minimum that both parties expect to become better off as a result of the transaction. Market generally relies on price adjustments to provide information to parties emerging in a transaction, so that each may accurately gang the subsequent change of their welfare. Markets are efficient when the price of goods or services attract exactly as much demand as the market can currently supply. The chief function of a market then is to adjust prices to accommodate fluctuations in supply and demand in order to achieve a locative efficiency.

\section{Ethnographic}

Ethnographic has been defined as the study of people in their natural or native environment-where they live, work, shop and play [7]. In a business or marketing research, ethnography is used to uncover, interpret and understand the consumer point-of-view and the hidden rules of environment. It provides a holistic view of consumers in the context of their daily lives. "Ethnography” literally means "a portrait of people”. Ethnography is a written description of a particular culture-the customs, belief, and behavior based on information collected through field work [8] (according to Ethnographic Insight [7], there is no substitute for the opportunity to experience what consumer experience). For example, consumers will not interact with any products and services in isolation, as they are affected by others variables such as unseen cultural factors in form of language, religion, belief and norms, among others and family patterns and other products and objectives in the proximate environment (Figure 1). Therefore, the best areas of getting at these unspoken cultural and social patterns that shape consumer behavior is through ethnographic marketing research (EMS). 


\section{Ethnography and Various Definitions}

Johnson [8] defined ethnography as "a descriptive account of social life and culture in a particular social system based on detailed observations of what people actually do". When used as a method ethnography typically refers to fieldwork (alternatively, participant observation) conducted by a single investigator who lives with and lives like those who are studied, usually for a year or more [9]. Ethnographic research comes from the discipline of social and cultural anthropology where an ethnographer is required to spend a significant amount of time in the field. Ethnographers immerse themselves in the life of people they study [10] and seek to place the phenomena studied in their social and cultural context. Developed within the academic discipline of cultural anthropology, ethnography is research conducted within the intimate context of real-world consumer experience. It facilitates an understanding of consumers' complex environments through direct observation and exploration of their own social, cultural, and economic vantage points. Ethnographic is a progressive marketing research methodology that emulates anthropological method of study in which naturalistic observation and semi structural interviewing are combined to see how consumers behave in their natural setting [11].

\section{Ethnic Marketing}

According to Perreault William [12], markets can be analyzed in terms of different ethnic grouping —ethnic markets. Such ethnic grouping can be people of different religion or race. Ethnic markets (Figure 3) are frequently found across more than one country, and can be significance to the marketer in formulating the marketing plan. To be able to have products and services acceptable globally, marketers must reflect the set of values held by these people in each segment of the market (Figure 3).

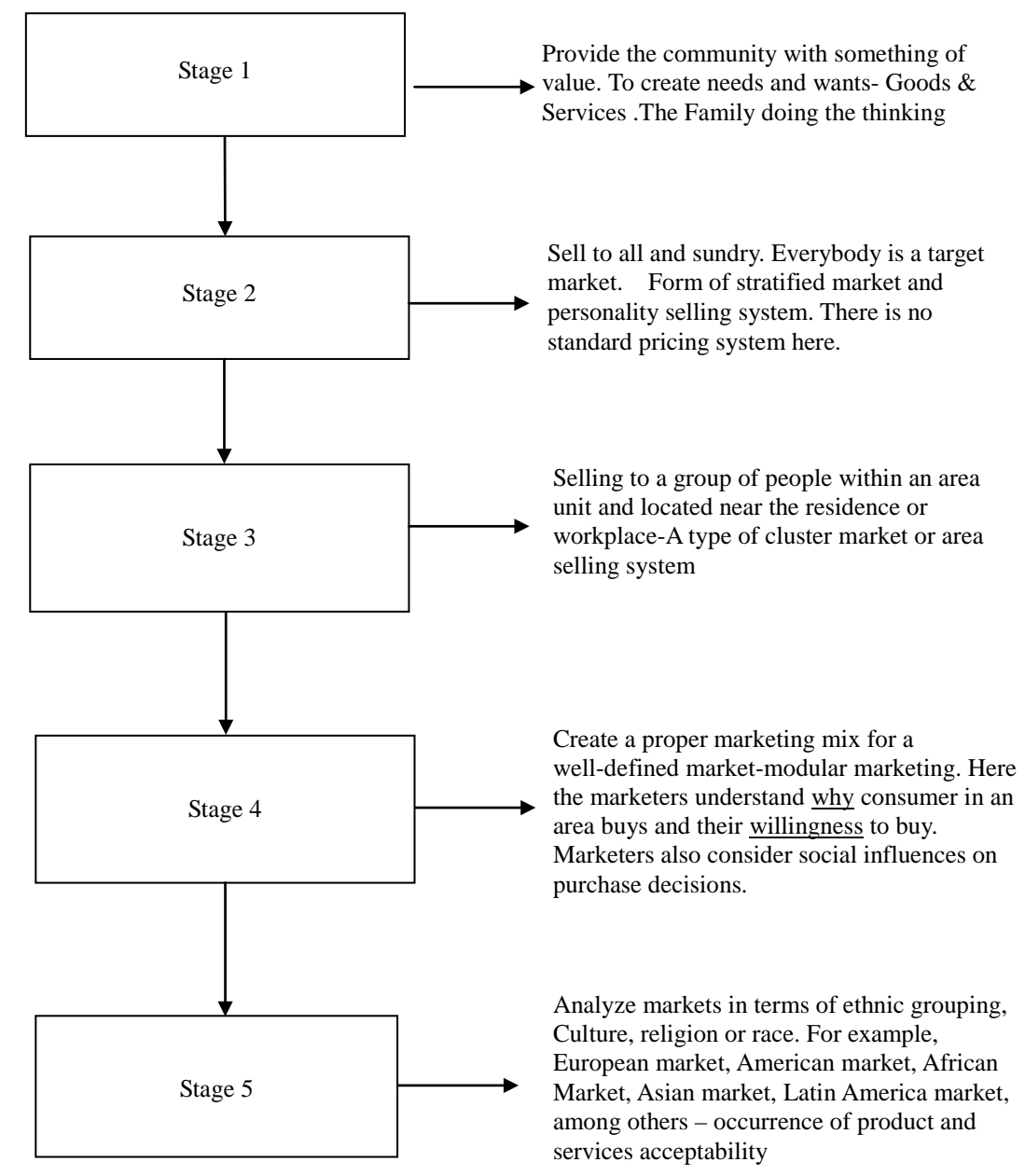

Figure 3. Development of ethnic marketing (Source: Research Survey, 2010). 
In the 1960s and 1970s, the heavily industrialized nations used global marketing strategy (GMS) in promoting goods and services throughout the world. The global marketing strategy (GMS) has been defined as the process of selling the same product, the same way, everywhere [13]. It was based on the idea that consumers around the world are growing more and more similar and that standardized products and market mix can achieve enormous economies of scale [4].

In the past, many multinational corporations (MNCs) have achieved tremendous success using this strategy (GMS) and operate profitably in many diverse markets. Nowadays, many multinational corporations have been less successful in using this method and deem it necessary to use other strategies such as modular marketing or use/need approach [14]. Modular marketing has been defined by Schewe [4] as centralized, coordinated strategy that is carried out in local units or modules and these modules may be either demographic or geographic and may even cross international boundaries [15].

\section{Consumer Behavior}

The goal of marketing generally is to provide satisfaction to ultimate consumers-buyers. Buyers therefore, are the focus of all marketing efforts and activities. It is on this note that marketers (domestic and international) put so much effort into collecting and analyzing information about markets (consumer \& industrial), market segmentation and targeting. In order to provide satisfaction, marketers need to understand the consumer's willingness to buy. They must understand why people behave as they do [4].

Lamb, Hair and McDaniel [16] observe that consumers' lives are in a constant state of flux and that as each generation grows and matures, it may adopt different sets of values and lifestyles than the previous generation. It was asserted further that a marketer must have a thorough and complete knowledge of consumer behavior to effectively accomplish the task of creating a proper marketing mix for a well-defined market (Figure 4). The Purchase Decision Making Process model in Figure 2 explains choice and desire of most consumers. Most Consumers pass through the Purchase Decision Making Process (Figure 2) and buyer's response (Figure 4).

\section{Regional Grouping and National Boundaries}

According to McCarthy and Perrrault, Jr. [17], consumers in the same country often share a common culture, and other uncontrollable variables which may be homogeneous. And for this reason it may be logical to treat consumers' countries as a dimension for segmenting markets. But sometimes it makes more sense to treat several nearby countries with similar culture as one region-Central America or Latin America or West Africa for examples. Or several nations that have bounded together to have common economic boundaries can be treated as a

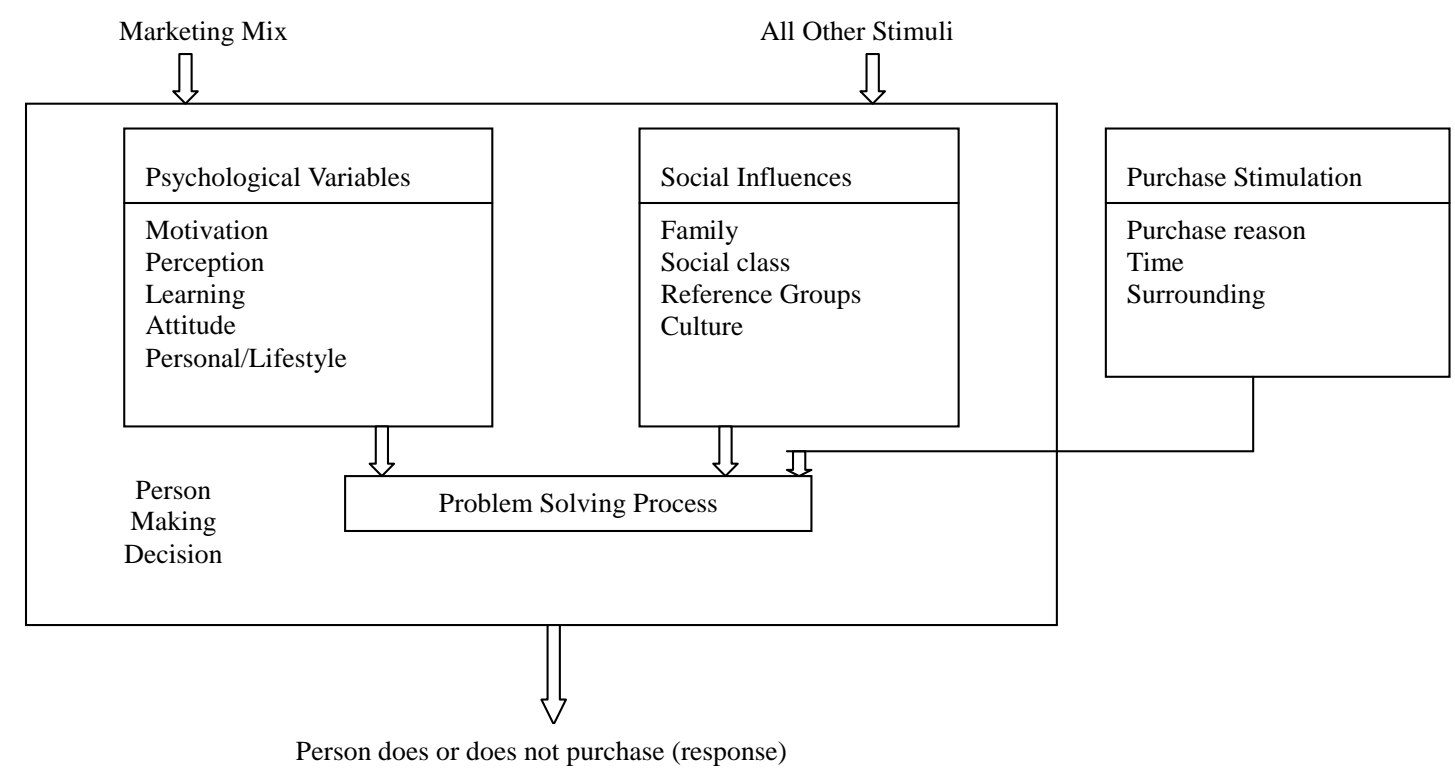


unit. The outstanding example is the movement towards unification of the 12 European Community (EC) countries [17].

Purchase decision making process that most consumers pass through before arriving at a decision to buy or not to buy.

\section{Buyer Motivation and Behavior}

To fully understand ethnographic marketing or cross cultural marketing it is very necessary to mention the motivation of buyer behaviors (Figure 4), the decision-making process (Figure 2), and the role of marketing efforts as a motivating influence. All activities are motivated. There is no behavioral act that takes place without some initiating force within the individual (Figure 5). These forces have been known as "motives" although some use the term "needs or wants for the same purpose". Motive therefore, is the state of the organism in which bodily energy is mobilized and selectively directed towards parts of the environment [18].

In any buying situation consumers search for the appropriate products or services and the places at which products/services can be purchased. His "perception" or sizing up of the various alternatives, however, is affected by many factors including: 1) values and attributes; 2) emotions; 3) response traits; 4) habitual patterns of behavior; 5) social influences; and 6) other stimuli from the environment. The interaction of these forces represents the psychological field as stated in Figure 5.

\section{Alaba International Marketing Pattern/Structure}

The governing body of Alaba International Market Trader Association (AITA) is made up of leaders of the various sections of the market.

Alaba International Market is segmented into eight (8) areas or sectors/departments as follows:

1) Line A-Warehousing for Imports: This segment is the section that distributes imported goods by the importers of electronics and allied goods and then distributes these goods to the wholesalers, retailers and industrial buyers.

2) Line B-Electronics Sales Section: These section deals with retail of electronics items such as televisions, video, musical instruments, and communication, computers, refrigerators, among others.

3) Line C-Repairs Section: These section of the market are those that repairs damaged electrical appliances such as computers, televisions, DVD players, sewing machines, generators, printers, photocopiers, among others.

4) Line D-Electrical Section: This section of the market deals mainly on electrical appliances such as household items, transformers, fashion and designs, furniture and fittings, building materials, among others.

5) Line E-Task Force/Security Section: Any customer with complains or product problems can contact the market task force personnel who will assist such customer. Each of the department of the market has security division.

6) Services Section: Services such as banking, insurance, barbing saloon, etc. are all over the market to provide other services for the smooth operations of the market. Other divisions of the market are: Task Force division, Traffic Section and Sanitation committee.

The market operates between 8.00 am to $6.00 \mathrm{pm}$ Monday to Saturday. And carry out environmental sanitations on Thursdays between 7.00 am to $10.00 \mathrm{am}$.

\begin{tabular}{|l|l|l|}
\hline Initiating force & \multicolumn{1}{|c|}{ Influences on perception of alternatives } & The outcome \\
\hline & $\begin{array}{l}\text { 1) Values and attitudes } \\
\text { 2) Emotions }\end{array}$ & \\
3) Response traits & \\
4) Habitual patterns of behavior & $\longrightarrow$ Purposeful behavior \\
5) Social influences & \\
6) Other stimuli from the environment & \\
and personal circumstances & \\
\hline
\end{tabular}

Intervention at forces in the psychological field 
Alaba International Market is a well organized market with three (3) major unions in operation. The unions are Igbo known as the Ndigbo; the Yoruba known as the Idera union comprises of the foods sellers and the allied and the Hausa known as Seriki union that are responsible for currency conversion among other activities.

The membership of the market stands at 5000 shops excluding attachments, kiosks and sub shops. There are about 100,000 traders in Alaba International Market made up of direct traders (shop owners) and indirect traders (agents, street registered traders, touts, etc.) [20]. An estimate of over one million people transacts business in congested Alaba market daily [20]. The market occupies a land area of approximately two kilometers by one kilometer on the Ojo Igbede road. The market can be accessed from Badagry on Badagry-Oshodi express way through Iyana Iba, and can also be reached from any part of Lagos via Mile 2/Festac Town. The market is also very popular because it is on the international boarder road leading to Seme and Ghana road [21].

\section{Other Notable Markets in Africa}

1) Merkato Market in Ethopia

2) Makola Market in Accra, Ghana

3) Bodija Market in Ibadan, Nigeria

4) Onitsha Market in Onitsha, Nigeria

5) Sokoto Central Market, Sokoto, Nigeria

6) Monday Market in Maiduguri, Nigeria

7) Kano Central Market in Kano, Nigeria.

8) Mokola Market in Ibadan, Nigeria [22]

9) Idumota Central Market, Lagos, Nigeria

10) etc.

Source: [23].

\section{Lagos State Industrial Policy}

Lagos State government as part of its continuing efforts to improve the environment for private sector investment in the state and thereby ensuring that the private sector plays the role expected of it as a major vehicle for the development and growth of the state economy has, after due consultation with the organized private sector, adopted the "Lagos State Industrial Policy" [24].

\section{The Broad Objectives of the Lagos State Industrial Policy}

The broad objectives of the Lagos State Industrial Policy are the attainment of a business climate that attracts, promotes and sustains private sector investment in the state economy especially in the preferred sectors as determined from time to time by government. 1) Integrated rural development and the balanced economic growth and development of the state; and 2) the sustenance of the state's premier position as the centre of industrial and commercial activities in the country [24].

\section{Lagos State Industrial and Commercial Zones}

The Commercial and industrial zones of Lagos State are: Ikeja, Apapa, Ilupeju, Matori, Oshodi/Isolo, Victoria Island, Ikoyi, Badagry/Ojo. Lekki, Mushin, etc. (Figure 6).

\section{Area of Study}

The study was conducted and carried out in Ojo Local government area of Lagos state where Alaba International Market is situated. The state is divided into industrial and commercial zones according to the State Government settings. The commercial and industrial zones of Lagos State are: Ikeja; Ilupeju; Matori; Oshodi/Isolo, Victoria Island; Ikoyi; Ikorodu; Lekki; Apapa; Mushin; Ojo/Badagry; Agage; Lagos Island, etc. (Figure 6) [25]. Lagos State has a population of about 9 million people [26] made up of various ethnic groups of Nigeria including other nationals. Lagos State is the nation's economic nerve centre with over 2000 industries and $65 \%$ of the country's commercial activities are carried out in Lagos State [15]. Two of the nation's largest seaports-Apapa and Tin-Can Ports are located in Lagos State [27]. 


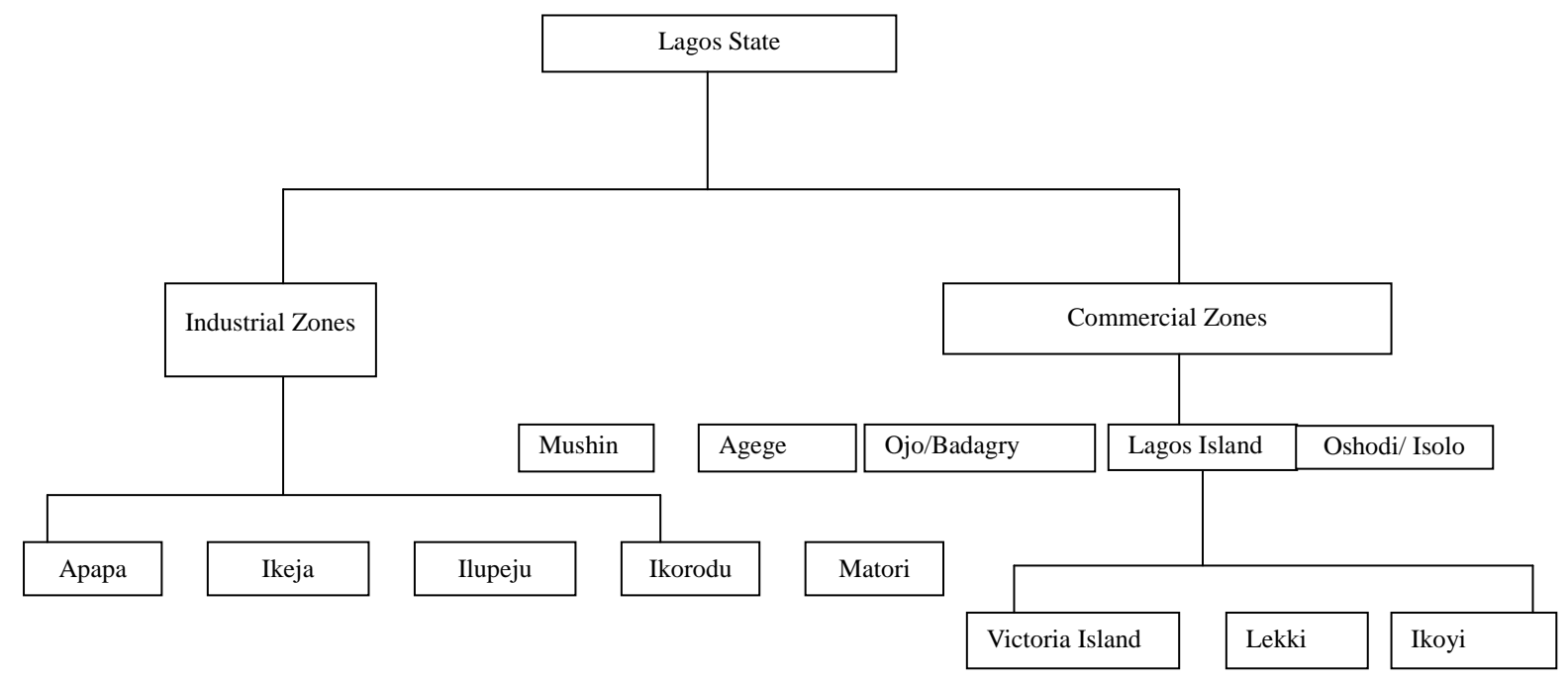

Figure 6. Lagos state industrial and commercial zones (Source: [25]).

\section{Methodology}

The study adopted ethnographic survey where both quantitative and qualitative approaches were used with selected samples of different ethnic groups of traders that were interviewed and observed at Alaba International Market. In this research, the questionnaires were divided into two parts namely; socio-demographic information and leading questions on the influence of ethnographic marketing on performance of business enterprises in Alaba International Market. The dependent variable, performance of business enterprises were measured according to jobs opportunities creation, growth and development, contribution of socio services, payment of taxes and levies and community development. The independent variable, marketing patterns of the entrepreneurs was observed as they carried out their daily business activities.

A total number of 585 questionnaires were distributed to business enterprises (respondents). The questionnaires were administered on the Chief Executives Officers who are the entrepreneurs and operators of the businesses. Out of the 585 questionnaires distributed only 400 were considered good for use for this study. Interview was conducted for 50 traders, while 200 business enterprises were observed and 120 local customers patronizing the market were also interviewed and 45 nationals of West Africa countries made up of 10 Ghanaians, 20 Togolese and 15 Beninois traders were also interviewed at Nigeria Seme boarder, using random sampling techniques. Nigeria Seme boarder is where traders and consumers take across products purchased from Alaba International Market to other neighboring West Africa countries. A random sampling technique was used to administer the questionnaires to entrepreneurs of Alaba and unstructured interview for other West Africa traders at the Nigeria/Seme border. Five point's Likert scale was used in the questionnaire range from strongly agree, agree, undecided, disagree and strongly disagree. Also, both dichotomous questions and rank order scaling were used in some parts of the questionnaire. And the simple percentage and chi-square method were used to analyze the data. Also content validity technique was used for the research instruments.

\section{Research Design}

The study adopted exploratory research design whereby both quantitative and qualitative exploration were used with selected samples of different social categories were interviewed. Since the research was more of exploratory in nature than analytical, then quantitative exploration was more appropriate here. Questionnaires were used to supplement data on the issues raised in the literature review and the conceptual framework, which could not be obtained from the secondary data.

\section{Research Instrument}

The research instruments used in gathering primary data are semi-structured questionnaire, observation, focus group discussion, and in-depth interview. It consisted of twenty-five formal questions designed to attract an- 
swers of limited responses. Some of the basic and salient questions that was asked including working experience form of business, business funding, level of capitalization, marketing ethnics, marketing pattern/system technological development, status years in business among others. The qualitative method consisted of in-depth interviews with the purposively selected Exco of the traders in Alaba International Market.

\section{Validation of Research Instrument}

The research instruments for this information by the respondents of both the traders and the Exco of the Alaba market in Lagos was carefully validated by experts and professionals in Entrepreneurial Institutes and Anthropology in Social Sciences of Obafemi Awolowo University, Ile-Ife, Nigeria. The research instrument is valid because several techniques were used to ask question on the influence of Ethnographic and Ethnic marketing on the performance of small-scale enterprises in Alaba International Market, Lagos state, Nigeria. The researcher seeks validation of the induced theory by going back to the members of the community under study for their reaction.

\section{Test of Hypotheses}

\section{Hypothesis 1 Using Questions 18 \& 25c section 1}

$\mathrm{H}_{\mathrm{o}}$ : There is no significant relationship between the ethnographic marketing patterns (EMPs) of Alaba International Market and the performance of business enterprises.

$\mathrm{H}_{1}$ : There is significant relationship between the ethnographic marketing patterns (EMPs) of Alaba International Market and the performance of business enterprises (Table 1).

$\mathrm{P}_{\text {value }}=268.864$

Degree of freedom $=9$

Level of significance $=0.05$

$\mathrm{X}^{2}$-calculated $=0.000$

From the above about, since chi-square calculated is 0.000 which is less than 0.05 level of significance, with the degree of freedom of 9; we therefore reject the null hypothesis $\mathrm{H}_{\mathrm{o}}$ and accept the alternative hypothesis $\mathrm{H}_{1}$ which states that there is significant relationship between the ethnographic marketing patterns (EMPs) of Alaba International Market and performance of business enterprises.

\section{Hypothesis 2 Tested Using Questions 21 \& 25c section 3}

$\mathrm{H}_{\mathrm{o}}$ : Alaba International Market pattern has not been meeting the industrial objectives of Lagos state.

$\mathrm{H}_{1}$ : Alaba International Market pattern has been meeting the industrial objectives of Lagos state (Table 2).

$\mathrm{P}_{\text {value }}=137.444$

Degree to freedom $=9$

Level of significance $=0.05$

$\mathrm{X}^{2}$-calculated $=0.000$

From the above about, since chi-square calculated is 0.000 which is less than 0.05 level of significance with the degree of freedom of 9; we therefore reject the null hypothesis $\mathrm{H}_{0}$ and accept the alternative hypothesis $\mathrm{H}_{1}$ which states that Alaba International Market pattern has been meeting the industrial objectives of Lagos state.

\section{Hypothesis 3 Tested Using Questions 20 \& 25c section 2}

$\mathrm{H}_{0}$ : There is no significance relationship between effects of Alaba International Market and economic development of business enterprises in the state.

$\mathrm{H}_{1}$ : There is significance relationship between effects of Alaba International Market and economic development of business enterprises in the state (Table 3 ).

$\mathrm{P}_{\text {value }}=570.887$

Degree to freedom $=9$

Level of significance $=0.05$

$\mathrm{X}^{2}$-calculated $=0.000$

From the above about, since chi-square calculated is 0.000 which is less than 0.05 level of significance, with the degree of freedom of 9; we therefore reject the null hypothesis $\mathrm{H}_{0}$ and accept the alternative hypothesis $\mathrm{H}_{1}$ which states that there is significance relationship between effects of Alaba International Market and economic development of business enterprises in the state. 


\section{Hypothesis 4 Tested Using Questions 19 and 25c}

$\mathrm{H}_{0}$ : There is no significance relationship between ethnic marketing practices and traders of Alaba International Market.

$\mathrm{H}_{1}$ : There is significance relationship between ethnic marketing practices and traders of Alaba International Market (Table 4).

$\mathrm{P}_{\text {value }}=14.500$

Degree to freedom $=6$

Level of significance $=0.05$

$\mathrm{X}^{2}$-calculated $=0.025$

From the above about, since chi-square calculated is 0.025 which is less than 0.05 level of significance, with the degree of freedom of 6; we therefore reject the null hypothesis $\mathrm{H}_{\mathrm{o}}$ and accept the alternative hypothesis $\mathrm{H}_{1}$ which states that there is significance relationship between ethnic marketing practices and traders of Alaba International Market.

21(b) Leading Question-in-depth interview, section B item (b): Are there any ethnic dominance of marketing system at Alaba market?

The above table reveals the various types of respondents in relation to ethnic patterns of Alaba International Market, out of 400 respondents, 9.0percent represents those that reported that the market was mostly dominated by Igbo people, 23.0 percent represent those that reported that the market comprises of Ibo, Hausa and Yoruba people, 58.8 percent reported that the market was mostly dominated with people from eastern part of the country while 9.3 percent represent those that reported that the market comprises of Igbo 81.8\%, Hausa 15\% and Yoruba $5 \%$.

\section{Results}

The results of the study show that:

152 out of 185 (82\%) respondents of the entrepreneurs that made up of the small scale enterprises operators of the market are from Eastern part of Nigeria (Ibos) — one ethnic group dominance (Table 5). 114 out of 120 (95\%) customers interviewed reveals that they patronize Alaba because of cheap, affordable and varieties of products. 87 out of 120 (72.5\%) Alaba customers interviewed are highly indifferent to product durability and after sales services. 173 entrepreneurs of Alaba and 120 customers interviewed believe that Alaba International Market contributed to the economic development of Lagos State, considering the high level of economic activities of that area, and various taxes paid to governments. 167 out of 185 (90\%) respondents of the entrepreneur of SMEs operators of Alaba market reveals that customers preferred imported products to locally made ones. 109 out of 120 (91\%) Alaba customers interviewed reveal that they come to Alaba because of foreign products varieties and different prices of the same product i.e. they prefer imported products to locally made ones and personality pricing systems being practiced in the market. All the nationals of other West Africa countries interviewed at the boarder have the same believes that Alaba International Market provides, cheap and affordable products of various categories and closeness to the boarder was another factors of easy transportation across boarder.

The study also reveals that there is significant relationship between ethnographic marketing patterns of Alaba International Market and the performance of business enterprises (hypothesis 1). That Alaba International Market patterns has been meeting the industrial objectives of Lagos State (hypothesis 2). That there exists significant

Table 5. Distribution of respondents according to ethnic marketing pattern in Alaba market.

\begin{tabular}{lcc}
\multicolumn{1}{c}{ Responses } & Frequency & Percent \\
\hline Mostly dominated by Igbo people & 36 & 9.0 \\
It comprises of Ibo, Hausa and Yoruba & 92 & 23.0 \\
Mostly dominated from Eastern part of the country & 235 & 58.8 \\
Igbos 80\%, Hausa 15\% and Yoruba 5\% & 37 & 9.3 \\
Total & 400 & 100.0 \\
\hline
\end{tabular}

Field Survey, 2010. 
relationship between effects of Alaba International Market and economic development of business enterprises in the State (hypothesis 3). That there is significant relationship between ethnic marketing practices and traders of Alaba International Market (hypothesis 4).

\section{Conclusions}

This study has shown that there is ethnic dominance of entrepreneurs in Alaba International Market. The findings also demonstrate that consumers and shoppers patronize the market because of cheap, affordable and easily accessible foreign products to people. In essence, there was a relationship between Alaba International Market and the economic development of Lagos State through SMEs performance. The major setback and problems associated with Alaba International Market in the course of this research work were:

1) Lack of adequate security for both traders and shoppers. The market is notorious from armed robbers attack.

2) Traffic congestion leading to the market posed problems for easy movement of goods and people.

3) Touts and fake products are another problems associated with the market.

There are some limitations to the study. There was no known previous study carried out on this work; hence this paper could not build or be based on previous work to validate the study. Most people that patronized this market from neighboring West Africa countries are both educated semi-illiterates.

\section{Recommendation}

The government should expand the scope of incentives and assistance to small scale enterprises in the State in such a way that the contribution of SSEs to the development of both socio and economic could be felt. The government should create an enabling environment for sustainable economic growth by providing entrepreneurs who are the operators of SSEs with cheap and constant power supply (energy), good and drinkable water supply, good and motor able network of roads, reliable security system, among others. The government should take more interest in the economy active participation of SSEs growth and development of the economy with a view of formulation of implementable laws, policies and regulations that will promote and create conducive environment for both local and foreign investors to operate profitable in the country. The government should come to the aid of small scale enterprises in the State by providing training opportunities for the SSEs operators, low interest loans facilities, technical supports, and credit facilities, among others. Also, the government should upgrade the standard, market facilities and roads leading to Alaba International Market to avoid congestion and make it easily accessible to anybody coming from any part of the city to the market. Entrepreneurs in Lagos State and Nigeria should take advantage of some of the programs and policies that have some effects on growth and development of SSEs.

\section{References}

[1] Daun, S. and Daun, S. (2007) Street Level Marketing.

[2] Gattiker, U.E. (1990) Technology Management in Organizations. Sage, California.

[3] Utterback, J.M. (1994) Mastering the Dynamics of Innovation. Harvard Business School Press, Boston.

[4] Schewe, C.D. (1987) Marketing, Principles and Strategies. London House, Inc., New York.

[5] Moschandreas, M. (2000) Business Economics. 2nd Edition, London Business Press, Thomas Learning.

[6] Ethnography (2005). https://en.wikipedia.org/wiki/Ethnography

[7] Ethnographic Insight (2008). http://www.ethno-insight.com/

[8] Harris, M. and Johnson, O. (2000) Cultural Anthropology. 5th Edition, Allyn and Bacon, Needham Heights.

[9] Van Maanen, J. (1996) Ethnography. In: Kuper, A. and Knper, J., Eds., The Social Science Encyclopedia, 2nd Edition, Routledge, London, 263-265.

[10] Lewis, I.M. (1985) Social Anthropology in Perspective. Cambridge University Press, Cambridge.

[11] Accessed on 15/09/08. http://www.baltimoreresearch.com

[12] Perreault, W.D. (2000) Basic Marketing. European Edition, McGraw-Hill Publishing Company, London, 52.

[13] Leavitt, T. (1983) The Globalization of Markets. Harvard Business Reviews, 61, 92-102.

[14] Keegan, W.J. (2002) Global Marketing Management. 7th Edition, Prentice Hall, Upper Saddle River. 
[15] Awoniyi, M.A. (2011) A Study of Ethnographic Marketing Patterns and Performance of Business Enterprises in Alaba International Market, Lagos, Nigeria. PhD Thesis, Obafemi Awolowo University, Ile-Ife.

[16] Lamb, C.N., Hair, J.E. and McDaniel, C. (1992) Principles of Marketing. South-Western Arbitrating Co., Mason.

[17] McCartby, J.E. and Perreault Jr., W.D. (1990) Basic Marketing: A Managerial Approach. Tenth Edition, Richard D. Irwin, Inc., Homewood, 582-584.

[18] McClelland, D.C. (1951) Personality. William Sloane Associate, New York. http://dx.doi.org/10.1037/10790-000

[19] Beckman, T.N. and Davidson, W.R. (1967) Marketing. 8th Edition, The Ronald Press Company, New York.

[20] Alaba Trade Association Book, 2010.

[21] https://en.wikipedia.org/wiki/Ojo, lagos state, 2008.

[22] Olaoba, O.B. (2000) Bodija Market in Ibadan 1987-1991. John Archers Ltd., Ibadan.

[23] https://en.wikipedia.org/wiki/Makola_market, 2011.

[24] Trade Policy Reviews: First Press Release. Secretariat and Government Summaries-Press/Tprb/75, 16 June 1998. Lagos State Investors Guide (1998) Lagos Eni-Meg Nigeria Limited.

[25] Awoniyi, M.A. (2006) An Assessment of State Government Industrial Policies on the Development of Small Scale Industries in Lagos State, Nigeria. M.Phil Thesis, Obafemi Awolowo University, Ile-Ife.

[26] National Population Commission-Censor 2006.

[27] Accessed on 28/16/08. http://www.lagosstate.gov.ng 


\section{Appendix A}

Instruction: Tick “ $\checkmark$ ” in the appropriate boxes.

\section{QUESTIONNAIRE FOR TRADERS}

Section A: Socio-Demographic Information

1. Age:
(a) Less than 21 years [
(b) 21 - 25 years [
(c) 26 - 30 years [
(d) above - 30 years

2. Sex:
(a) Male [
(b) Female [ ]

3. Marital Status:
(a) Single [ ]
(b) Married [ ]
(c) Widowed [
(d) Divorced [
(e) Separated [ ]

4. Religion:
(a) Christian [ ]
(b) Muslim [
(c) Traditional [
(d) No Religion [ ]
(e) Others (specify)

5. Educational level:
(a) None [
(b) Primary school [
] (c) Secondary school [
(d) Post secondary [
(e) Others (specify)

6a. State of Origin:
(a) Yoruba
(b) Igbo [

6b. Ethnic group

7. Local Government:

8. Town:

9. Place of Residence: Rural [ ] Urban [ ]

10a. Year of experience:
(a) less than 10 yrs
] (b) 10 - $15 \mathrm{yrs}$ [
]
(c) 16 - 20 yrs [ ]
(d) 21-25yrs [
(e) above 26 yrs [ ]

$10 \mathrm{~b}$. What is the average number of customers that you receive on daily basis?
(a) 1 - 10 [
(b) $11-20$ [
(c) 21 - above [ ]

11. How would you describe most of your customers?
(a) Highly educated
(b) Educated [
(c) Not educated [
(d) others (specify)

12a. Do you belong to any Traders association?
(a) Yes [
(b) No

$12 \mathrm{~b}$. If Yes, what is the name of your association (s)?

12c. Do you hold any position in your association

(a) Yes [ ] $\quad$ (b) No [ ]

12d. If Yes, what is your position?
(a) President [ ]
(e) others (specify)
(b) Vice [
(c) Secretary [ ]
(d) P.R.O [ ]

13a. How long have you been in this market?

$13 \mathrm{~b}$. What exactly do you sell in this market?

14. How would you describe your relationship with public (clients)? (Tick one)
(a) Very cordial [
(b) Cordial [
(c) Indifferent [
(d) Not cordial [ ]

15. How do you see your career? (Tick one).
(a) Very attractive [
(b) Very good business [
(c) Bad business [ ]

Section B: General questions on Alaba International Market

16. What are the marketing patterns of Alaba International Market? 
17. Explain the performance of small-scale enterprises in Alaba International Market?

18. Assess the ethnographic marketing patterns of Alaba International Market?

19. What are the ethnic marketing practices among traders in Alaba International Market?

20. What are the effects of Alaba International Market on the economic development of small-scale enterprises in Lagos?

21. What can you say about Alaba International Market and Industrial objectives of Lagos state?

22a. Please indicate your level of involvement in the channels of distribution of the products you are selling. (Tick as many options as necessary).
(a) Wholesalers [ ]
(d) Others (specify)
(b) Retailers [ ]
(c) Direct to consumers [ ]

22b. Do you usually get all your products in Nigeria?

Yes [ ] No [ ]

22c. If No, where did you get your materials?

23. Please, list your major materials and the locations for getting them?

\begin{tabular}{|c|c|c|c|}
\hline S/No & Major products & Location within the state & Location outside the state \\
\hline \multicolumn{4}{|l|}{1.} \\
\hline \multicolumn{4}{|l|}{2.} \\
\hline \multicolumn{4}{|l|}{3.} \\
\hline \multicolumn{4}{|l|}{4.} \\
\hline \multicolumn{4}{|l|}{5.} \\
\hline 6. & & & \\
\hline
\end{tabular}

24. Please kindly tick from the list below the categories of people you sell to?
(a) General public [
(b) Companies or Organizations [
] (c) Governments [ ]
(d) Anyone that comes [
] (e) Others (specify)

25a. As a Trader, are you in support of the free duty on all commodities imported to Nigeria in the nearest future?

Yes [ ] No [ ]

25b. If yes, which of the following are the reasons? (Pick only one of the alternative responses: $5=$ Strongly 
agree, 4 = Agree, 3 = Undecided, 2 = Disagree, 1 = Strongly disagree

\begin{tabular}{|c|c|c|c|c|c|c|}
\hline $\mathrm{S} / \mathbf{N}$ & Items & S.A & A & UND & $\mathbf{D}$ & SD \\
\hline 1. & To make prices of all commodities cheaper & & & & & \\
\hline 2. & For easy accessibility and affordability of commodities & & & & & \\
\hline 3. & For the benefit of the poor majority of Nigerian population & & & & & \\
\hline 4. & It will improve the rate of our sales & & & & & \\
\hline
\end{tabular}

25c. To what extent do you agree with the following statements as regards the performance of Alaba Internal Market in the Lagos State economy. Answer by choosing any of the following options: 5, 4, 3 ,2, 1

Strongly Agreed (SA) - 5

Agree (A) - 4

Undecided (U) - 3

Disagree (D) - 2

Strongly Disagreed - 1

S/N Items $\quad$ ItN $\quad \begin{array}{lllll}5 & 4 & 3 & 2 & 1\end{array}$

1. Alaba International Market activities creates employment opportunities for a wide range of people in the state

2. Alaba International Market foster economic growth of the state through small business development creation

3. Alaba International Market through payments of various taxes and levies to government contributed to the economic and social development of Lagos state.

The activities of Alaba International Market have positive impact on the

4. economic development of Lagos State through provision of social services and income generation.

5. Alaba International Market contributes to the provision of infrastructure facilities to Ojo local government and promotes sustainable growth of the area.

26a. Do you have difficulties in accessing your products?

Yes [ ] No [ ]

26b. If yes, please indicate the severity of problems in your business?

\begin{tabular}{cllll}
\hline S/No & \multicolumn{1}{c}{ Problems } & Very severe & Severe & Not severe \\
\hline 1. & Scarcity of products & \\
\hline 2. & High duty on products & \\
\hline 3. & Storage & \\
\hline 4. & Price fluctuations & \\
\hline 5. & Others (specify) & \\
\hline
\end{tabular}

26c. What would you consider as the common problems faced by Alaba market traders? Tick only one response: 5 = strongly agree, 4 = Disagree, $3=$ Undecided, 2 = Agree, $1=$ Strongly disagree 


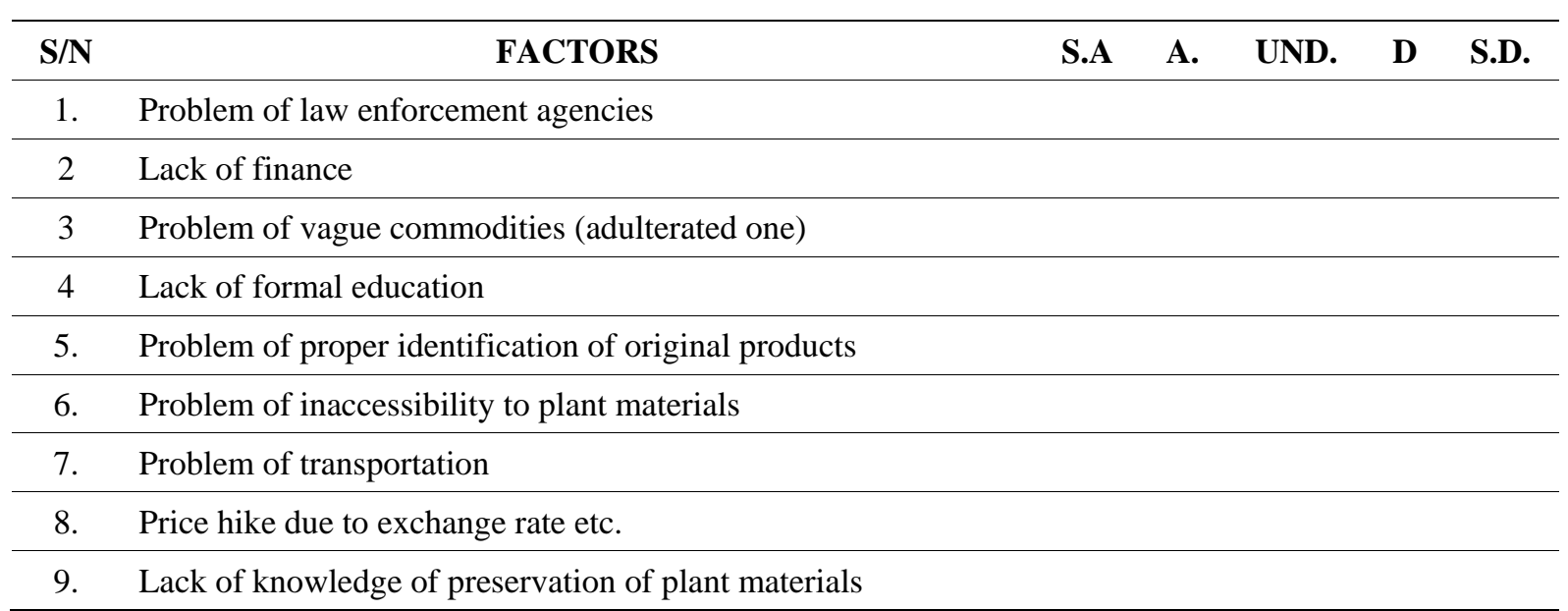

27. Please indicate the type of assistance rendered by the Government to your enterprise (Tick as necessary):
(a) Training [ ]
(b) Technical support [
(c) Financial Support [ ]
(d) Others (specify)

28. What type of assistance/facilities do you require to enhance your performance? Score the following in order of importance I $=$ Very important $2=$ important $3=$ Not important

\begin{tabular}{|c|c|c|c|}
\hline S/No & Assistance /Facilities & Tick & Score \\
\hline 1. & Finance i.e. make loan available to traders & & \\
\hline 2. & Training i.e. on knowledge of invention and manufacturing of products & & \\
\hline 3. & Improved transport facilities & & \\
\hline 4. & Technical support i.e. setting up testing laboratories for detecting vague products & & \\
\hline 5. & Improved public water supply & & \\
\hline 6. & Easy accessibility to movable products & & \\
\hline
\end{tabular}

Thank You.

\section{Appendix B}

\section{Section A: Personal Data}

\section{IN-DEPTH INTERVIEW GUIDE}

\section{LEADING QUESTION}

Respondent's age, marital status, religion, sex, state of origin, local government, and occupation among others.

\section{Section B: General Questions on Traders}

The research attempted to answer the following questions:

a. Are there any ethnic dominance of marketing system at Alaba market?

b. Does Alaba International Market offers cheap, low and inferior products to consumers?

c. What are the sources of the products being sold in the market?

d. Are the products manufactured locally?

e. If yes, where are they producing them in Nigeria?

f. Where are those imported products of the market coming from?

g. Does Alaba International Market serves as dumping ground for substandard products in West Africa?

h. Are there any marketing ethnic's practices among the marketers of Alaba International Market?

i. Specially, does Alaba International Market contribute to the growth of SSE's in Lagos State?

j. What are the marketing patterns of Alaba International Market? 
$\mathrm{k}$. Are there ethnic marketing practices among traders of Alaba market?

l. If yes, how do they practice it?

$\mathrm{m}$. What are the performances of small-scale enterprises in Alaba International Market?

n. How can you assess the ethnographic marketing patterns of Alaba International Market?

o. What are the effects of Alaba International Market on the economic development of small-scale enterprises in Lagos state?

p. What are the relationship between Alaba market and Industrial objectives of Lagos state?

q. Proffer a solution to ethnographic marketing patterns of Alaba International Market on the performance of small-scale enterprises in Lagos state, Nigeria?

r. What do you think should be done to assist Traders in Alaba International Market Lagos state, Nigeria? 